DOI: 10.31548/machenergy.2020.02.059-066

УДК 519.8:656.135.073:658.8.036.6:338.432

\title{
ASSESSMENT MODEL OF RISK TOLERABILITY LEVEL OF PERISHABLE AGRICULTURAI PRODUCTS TRANSPORTATION
}

\author{
O. M. Zagursky \\ National University of Life and Environmental Sciences of Ukraine. Ukraine. \\ Speciality of article: 275 - transport technologies (by road). \\ Corresponding author:zagurskiy_oleg@ukr.net.
}

Article history: Received - January 2020, Accepted-April 2020.

Bibl. 8, fig. 2, tabl. 4.

Abstract. The level of risk tolerability for agricultural supply chains due to its characteristics, primarily related to limited shelf life, is a complex indicator that reflects the likelihood of an occurrence and the severity of an adverse event (risk event).

At that, a significant number of external and internal environmental factors expressed in the aggregate of certain indicators have the impact on the fact of the occurrence of a risk event. The significance of these indicators, as well as the vector of their power of influence, is unique to each individual factor. However, transport factors indicators influencing the riskiness of supply chains have the greatest influence and some uniqueness in logistics.

The article proposes the system of factors typified by indicators reflecting the influence of the internal and external environment on the risk level of the transportation process of perishable agricultural products with fuzzy multiple approach being one of the most suitable for the development of the assessment model of logistical risks level in the process of perishable agricultural products transportation.

On the basis of the defined system of indicators, a fuzzy-multiple assessment model of the proposed logistics risk groups tolerability has been developed. In accordance with the defined approach, it is proposed, first of all, to assess the level of tolerability of all possible transportation scenarios implementation accepted apart from economic indicators.

A scenario that does not meet the regulatory norms of the logistical risk tolerability level should be automatically excluded from the list of potential for implementation regardless of its level of economic attractiveness.

Key words: agricultural products, supply chains, risk, metrics, transportation.

\section{Introduction}

The level of risk tolerability for agricultural supply chains due to its characteristics, primarily related to limited shelf life, is a complex indicator that reflects the

likelihood of an occurrence and the severity of an adverse event (risk event).

At that, a significant number of external and internal environmental factors expressed in the aggregate of certain indicators have the impact on the fact of the occurrence of a risk event.

\section{Formulation of problem}

The significance of these indicators, as well as the vector of their power of influence, is unique to each individual factor.

However, transport factors indicators influencing the riskiness of supply chains have the greatest influence and some uniqueness in logistics.

The importance of logistical risks is difficult to overestimate. Thus, according to a survey conducted at the initiative of Oracle [5], more (77\%) of the responding companies suffer from unforeseen failures in the "value chains".

Therefore, to determine the systems of factors that influence the level of logistical transportation risk tolerability, it is necessary to conduct theoretical and empirical analysis in terms of the types of these risks.

\section{Analysis of recent research results}

It should be noted that Supply Chain Risk Management (SCRM) is a new area of research in the context of the overall Supply Chain Management (SCM) strategy (Nooraie, Parast 2015 [3]). SCRM views risk as a situation that entails the impact of two main elements: incident and uncertainty about possible consequences (Bandaly, Satir, Shanker 2014 [1]; Nyaga, Lynch, Marshall., Ambrose 2013 [4], Vilko, Ritala, Edelmann 2014 [7]).

Given that in today's disordered and highly dynamic market environment, each supply chain is susceptible to devastating effects turbulence creates a situation in which SCRM becomes paramount for 
organisational survival and wealth (Wildgoose, Brennan, and Thompson 2012 [8]).

In experts' opinion, it is necessary to develop a comprehensive strategy that meets the following needs. Firstly, they are the strategies that help companies minimize costs and increase customer satisfaction (Chen J, Sohal A. S., Prajogo D. I. (2016) [2]). Secondly, they are the strategies that should enable companies to carry out their operations during and after the incident (Tang, Musa 2011 [6]).

\section{Purpose of research}

The purpose of the work is to develop a system of factors expressed in indicators reflecting the influence of the internal and external environment on the risk level of the transportation process of perishable agricultural products.

\section{Results of research}

Typically, a risk management system is built in the form of a Deming cycle (or Deming - Schuhart) - PDCA cycle (from words: plan, execute (do), check (check study), act (act)). Therefore, the supply chain risk management cycle can be represented as follows (Fig. 1).

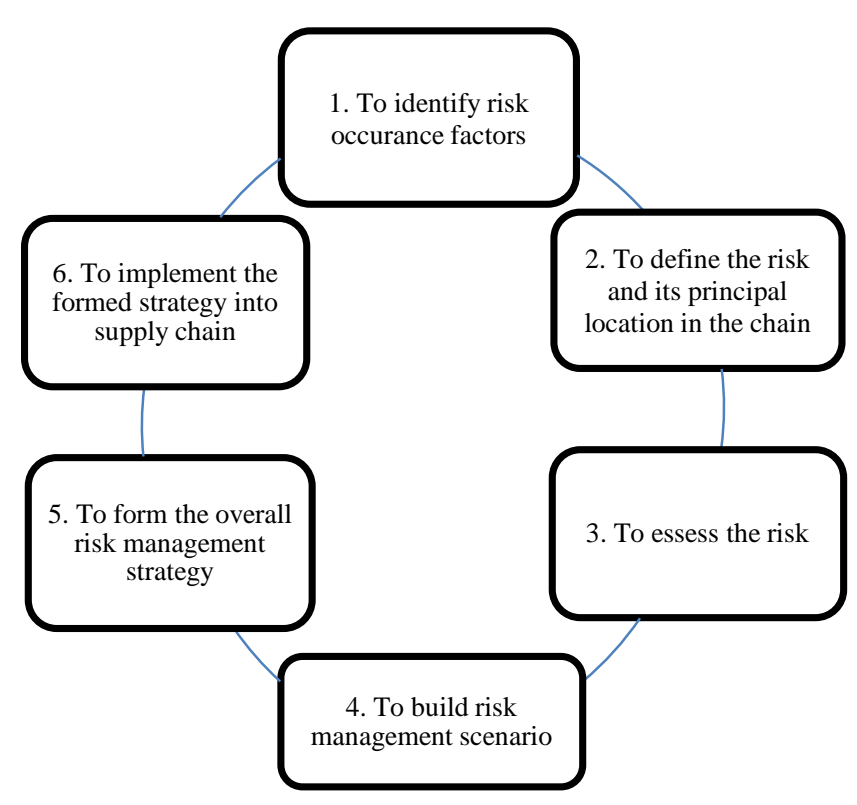

Fig. 1. Supply chain risk management cycle. Source: Compiled by the author.

The analysis of the risk situation identifies three interrelated conditions: the presence of uncertainty, the analysis of possible development alternatives, and the choice of the ability to assess the likelihood of implementing the chosen risk management options.

It should be noted that in this case only the process of transport logistics of perishable agricultural products is investigated, hence the choice of a particular mode of its transportation. To this end, the most important groups of risk factors associated with this stage of the supply chain will be considered, namely material, operational and social risks.

Consider consecutively the groups given:

Material risks. These risks characterize the cumulative adverse effect on the quantitative and/or qualitative integrity of the goods being carried. The following are the factors that influence the level of these risks:

1. The presence of supervisory staff. The presence of specially trained personnel able to respond in a timely manner to the violation of the conditions of transportation of perishable goods contributes to a significant reduction of the potential loss and the likelihood of realization of a risky situation.

2. The impact of this factor is inverse to the level of risk. The level of influence of this factor can be assessed by the following indicators:

a. The number of supervisory staff. Legend Fr/m-1. Units are people. Measured statistically. An increase in this indicator leads to an increase in the influence of the factor.

b. The qualification of supervisory staff. Legend $\mathrm{Fr} / \mathrm{m}-2$. Units are points. Measured expertly. An increase in this indicator leads to an increase in the influence of the factor.

3. Length and specificity of the route. As the length of the journey increases, the likelihood of quantitative and/or qualitative damage to the cargo increases. The impact of this factor is directly related to the level of risk. The level of influence of this factor can be assessed by the following indicators:

a. Cumulative route length. Legend - Fr/m-3. Units of measurement - km. Measured statistically. An increase in this indicator leads to an increase in the influence of the factor.

b. The number of accidents committed on the road over the last 2 years according to the statistics of the Ministry of Internal Affairs. Legend - Fr/m-4. Units pieces (pcs). Measured statistically. An increase in this indicator leads to an increase in the influence of the factor.

4. Weather conditions. Worsening of weather conditions can lead to violations of the integrity of the transport packaging, and to the deterioration of the ability to control the transportation process. The impact of this factor is inverse to the level of risk. The level of influence of this factor can be assessed using the indicator:

a. qualitative assessment of the results of the weather forecast. Legend - Fr/ m-5. Units - score. Measured expertly. An increase in this indicator reduces the impact of the factor.

Operational risks. These risks characterize the cumulative adverse effect of external and internal environmental factors on the operation of the freight rolling stock.

The realization of these risks can lead to the realization of environmental risks. However, these risks are largely technical in nature. The following factors can be identified as factors affecting the level of operational risks: 
1. Wear of the rolling stock. This factor is crucial in ensuring the continuity of the transportation process. The impact of this factor is directly related to the level of risk. The level of influence of this factor can be assessed by the following indicators:

a. The wear factor of the rolling stock. This indicator is calculated as the accumulated depreciation to the original value of the rolling stock. Legend - Fr/e1. Units of measurement - \%. Measured statistically. An increase in this indicator leads to an increase in the influence of the factor.

b. the proportion of regulatory time elapsed since the last scheduled rolling stock maintenance. This figure is calculated as the ratio of the time remaining to the next scheduled maintenance and the regulatory time between scheduled maintenance. Legend - Fr/e-2. Units of measurement - \%. Measured statistically. A decrease in this indicator leads to an increase in the influence of the factor.

2. Load on the roadbed. This factor is purely technical. Its impact has a well-defined vector and a direct relationship to the level of risk. The level of influence of this factor can be assessed by the following indicators:

a. exceeding the permissible level of axle load. The calculation of this indicator is carried out by dividing the current level of load by the axis to its normative value. Legend - Fr/e-3. Units of measurement - \%. Measured statistically. An increase in this indicator leads to an increase in the influence of the factor.

b. exceeding the permissible load level by 1 meter of the roadway. The calculation of this indicator is carried out in accordance with the calculation of the indicator Fr/e-3. Legend - Fr/e-4. Units of measurement - \%. Measured statistically. An increase in this indicator leads to an increase in the influence of the factor.

2. Wear of pavement. This factor is exclusively external to the transport enterprise. The impact of this factor is directly related to the level of risk. The level of influence of this factor can be assessed by the following indicator:

a. the proportion of regulatory time elapsed since the repair of the road. This figure is calculated as the ratio of the time remaining to the next scheduled maintenance and the regulatory time between scheduled maintenance. Legend - Fr/e-5. Units of measurement $\%$. Measured statistically. A decrease in this indicator leads to an increase in the influence of the factor.

Social risks. These risks combine a set of adverse events, the source of which is the "human factor". The realization of social risks can lead to operational risks, which in turn can lead to environmental risks. The following are the factors that influence the level of these risks:

1. Sufficiency of the staff. This factor is decisive in terms of the ability to realize social risks. The impact of this factor is directly related to the level of risk. The level of influence of this factor can be assessed by the following indicator:

a. staffing of the enterprise. This indicator is calculated by the ratio of personnel available at the enterprise to the number required for the tasks. Legend Fr/s-1. Units of measurement - \%. Measured statistically. A decrease in this indicator leads to an increase in the influence of the factor.

2. Staff qualification. The impact of this factor is inverse to the level of risk. The level of influence of this factor can be assessed by the following indicator:

a. Average skill level of the staff. This indicator is calculated as the ratio of the sum of qualifications (expressed in points) and the total number of the staff evaluated. Legend - Fr/s-2. Units of measurement point/person. Measured expertly. An increase in this indicator leads to an increase in the influence of the factor.

3. Staff experience. Combined work experience allows the employee to develop practical skills based on algorithms for eliminating the consequences in terms of risk. The nature of the influence of this factor on the integral result is comparable to the nature of the influence of the previous factor. The level of influence of this factor can be assessed by the following indicator:

a. average experience of the staff involved. The calculation of this indicator agrees with the indicator $\mathrm{Fr} / \mathrm{s}-2$. Legend - Fr/s-3. Units of measurement point/person. Measured statistically. An increase in this indicator leads to an increase in the influence of the factor.

The formed system of indicators is rather heterogeneous. The degree of impact of each factor on the integrated indicator as well as each individual indicator on the influence of the factor is different. So, it makes sense to build a balanced scorecard.

The assignment of weight to each of the selected indicators can be carried out using a combined approach, which involves both expert weight distribution and weight distribution in accordance with Fishburn's law.

For these purposes, the factors were ranked by experts by the degree of impact on the end result. In this case, the distribution of weight within the groups themselves is made uniformly to prevent weight gain of those factors, which are assessed by several indicators. The results of the distribution are represented in Fig. 2.

The assessment of all selected groups risk tolerability cannot be provided on the basis of classical methods of risk assessment.

First of all, this is due to the need to use both statistical (formalized) and expert (unformalized) indicators that characterize the level of risk. Moreover, the complexity of the object of study determines the need to identify fuzzy assessment intervals, as well as characterized by the level of confidence of the expert in the conclusions drawn.

Therefore, a fuzzy-multiple approach is one of the most suitable for building an assessment model for the level of logistical risks of perishable agricultural products transportation process.

Building an assessment model using fuzzy logic involves the following steps:

1. Independent variables are selected, the consequence factors that influence the value of the dependent variable.

2. Fuzzy sets of values for independent and dependent variables are described. In this case, instead of numerical values, linguistic terms are used. 
3. Output rules are described. Each rule is written as "if" (independent variable is equal to value), "then" (dependent variable is equal to value). In this case, as the "values" are used the linguistic terms described in paragraph 2.
4. Fuzzy sets of the dependent variable are generated based on independent variables and output rules. Software is usually used to implement this step.

5. The result is then used for informed decision making.

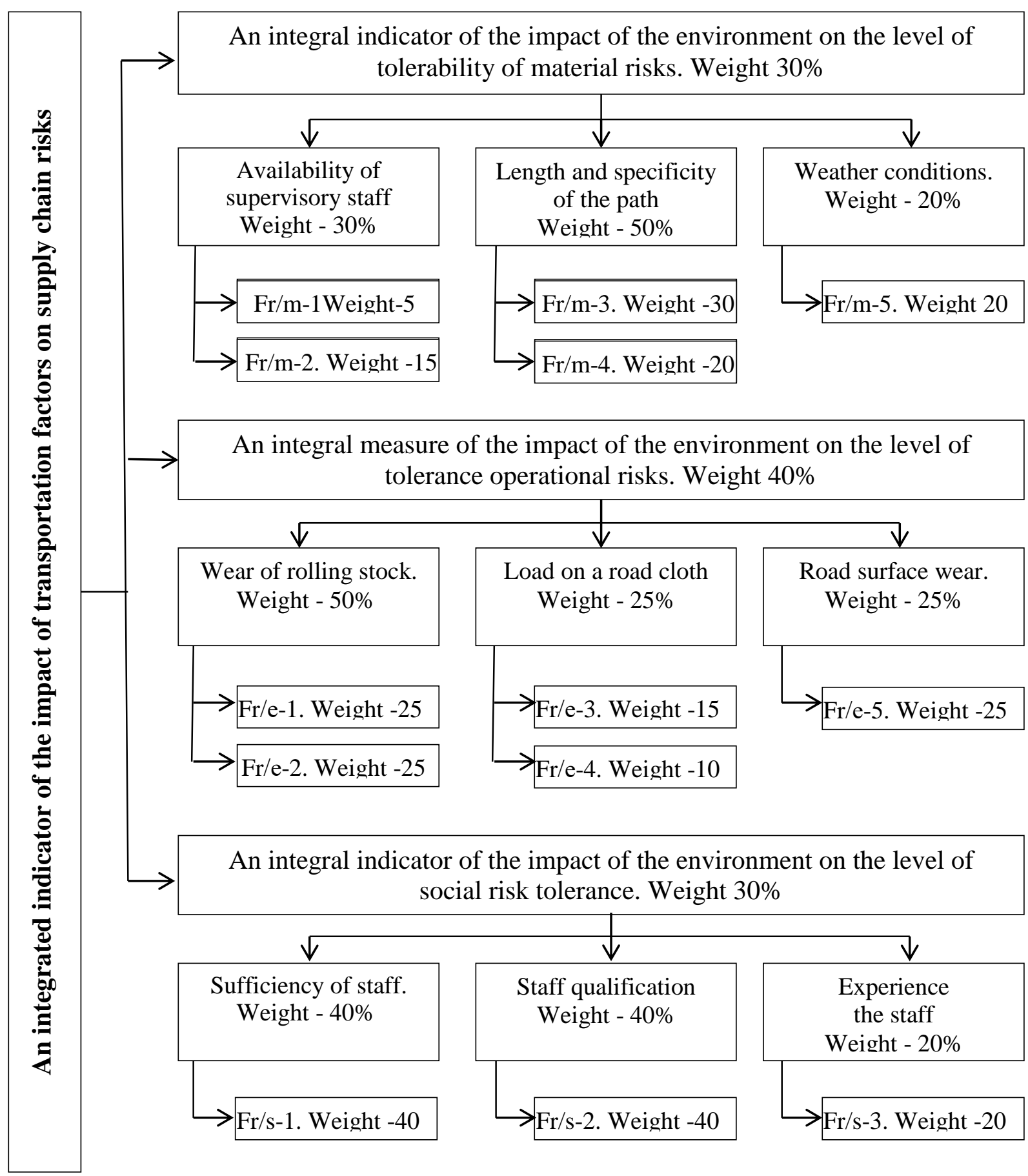

Fig. 2. Balancing weights of the integrated impact model on the risk tolerability level of the transportation process.

Source: Compiled by the author

According to the above algorithm, the stages of modeling occur.

Stage 1 (sets). Introduce the following basic sets and subsets of states described in natural language:

a) The complete set of state $G$ of an enterprise is broken down into five types of subsets:

- G1 - a subset of "extremely low risk probability";
- G2 is a subset of "the degree of risk is negligible";

- G3 is a subset of "medium risk";

- G4 is a subset of "high risk";

- G5 is a subset of "extremely high risk probability".

Hereinafter, we assume that the index G takes a value from zero to one by definition. 
We construct a set of individual indicators $X=\{\mathrm{Xi}\}$ by the total number $\mathrm{N}$, which, according to the expert analyst, on the one hand, analyze the likelihood of a risk situation, and, on the other hand, assess the different nature of the transportation process in the supply chain.

Step 3 (Significance). Let us compare each indicator of $\mathrm{Xi}$ with the level of its significance for the analysis of ri. To assess this level, you must place all the metrics in descending order $r_{1} \geq r_{2} \geq \ldots r_{N}$ so that the rule is followed. Ranking is by Fishburn rule:

$$
r_{i}=\frac{2(\mathrm{~N}-\mathrm{i}+1)}{(\mathrm{N}-1) \mathrm{N}}
$$

Step 3 (Classification of metric values). The function of the value of the deviation of the factorconsequence is given by a fuzzy set:

$$
\mu_{[0 ; 1]}\left(X_{s}^{r}\right)=\left\{X_{s_{1}}^{r} / V_{1}, X_{s_{2}}^{r} / V_{2}, \ldots ., X_{s_{n}}^{r} / V_{n}\right\}
$$

where $-X_{s_{1}}^{r}, \ldots, X_{s_{n}}^{r}$ the value of the factor after increase,

$\mathrm{V} 1, \ldots, \mathrm{Vn}$ - subjective estimates of the possibility of corresponding increases in the factor-consequence at a given increase in the factor-cause.

The following is a classification of the current values of $X$ as the criteria for splitting the complete set of its values into subsets of the form B.

Step 4 (Risk classification of the transportation process). We construct a classification of the current value of $\mathrm{g}$, the indicator of riskiness $\mathrm{G}$, as a criterion for the division of this set into subsets.

Step 5 (Classification of metric values). Let us construct a classification of the current values of $\mathrm{X}$ as a criterion for splitting the complete set of its values into subsets of the form B.

Table 1. Classification of the current values of indicators $X$.

\begin{tabular}{|c|c|c|c|c|c|}
\hline \multirow{2}{*}{ Indicator } & \multicolumn{5}{|c|}{ The criterion of division into subsets } \\
\cline { 2 - 6 } & $\mathrm{B}_{\mathrm{i} 1}$ & $\mathrm{~B}_{\mathrm{i} 2}$ & $\mathrm{~B}_{\mathrm{i} 3}$ & $\mathrm{~B}_{\mathrm{i} 4}$ & $\mathrm{~B}_{\mathrm{i} 5}$ \\
\hline $\mathrm{X}_{1}$ & $\mathrm{x}_{1}<\mathrm{b}_{11}$ & $\mathrm{~b}_{11}<\mathrm{x}_{1}<\mathrm{b}_{12}$ & $\mathrm{~b}_{12}<\mathrm{x}_{1}<\mathrm{b}_{13}$ & $\mathrm{~b}_{13}<\mathrm{x}_{1}<\mathrm{b}_{14}$ & $\mathrm{~b}_{14}<\mathrm{x}_{1}$ \\
\hline$\cdots$ & $\cdots$ & $\cdots$ & $\cdots$ & $\cdots$ & $\cdots$ \\
\hline $\mathrm{X}_{\mathrm{N}}$ & $\mathrm{x}_{\mathrm{N}}<\mathrm{b}_{\mathrm{N} 1}$ & $\mathrm{~b}_{\mathrm{N} 1}<\mathrm{x}_{\mathrm{N}}<\mathrm{b}_{\mathrm{N} 2}$ & $\mathrm{~b}_{\mathrm{N} 2}<\mathrm{x}_{\mathrm{N}}<\mathrm{b}_{\mathrm{N} 3}$ & $\mathrm{~b}_{\mathrm{N} 3}<\mathrm{x}_{\mathrm{N}}<\mathrm{b}_{\mathrm{N} 4}$ & $\mathrm{~b}_{\mathrm{N} 4}<\mathrm{x}_{\mathrm{N}}$ \\
\hline
\end{tabular}

Source: Nedosekin, A.O. Fuzzy-multiple approach to actuarial modeling [Electronic resource] / AO Nedosekin. Access mode: http: // pensionreform.ru/, free.

Step 6 (Measurement Level Assessment). Let's evaluate the current level of indicators and summarize the results in the table.

Table 2. Assessment of the current level of indicators.

\begin{tabular}{|l|l|}
\hline \multicolumn{1}{|c|}{ Indicator } & \multicolumn{1}{c|}{ The current value } \\
\hline $\mathrm{X}_{1}$ & $\mathrm{X}_{1}$ \\
\hline$\cdots$ & $\cdots$ \\
\hline $\mathrm{X}_{\mathrm{N}}$ & $\mathrm{X}_{\mathrm{N}}$ \\
\hline
\end{tabular}

Source: Nedosekin, A.O. Fuzzy-multiple approach to actuarial modeling [Electronic resource] / AO Nedosekin. Access mode: http: // pensionreform.ru, free.

Step 7 (Classification of indicators). We classify the current values of $x$, where $\lambda_{\mathrm{ij}}=1$ if $b_{\mathrm{i}(\mathrm{j}-1)}<\mathrm{x}_{\mathrm{i}}<\mathrm{b}_{\mathrm{ij}}$, and $\lambda_{\mathrm{ij}}=0$, otherwise (when the value does not fall within the selected classification range).

Table 3. Indicator level classifications.

\begin{tabular}{|l|l|l|l|l|l|}
\hline \multirow{2}{*}{ Indicator } & \multicolumn{6}{c|}{ The result of classification into subsets } \\
\cline { 2 - 7 } & \multicolumn{1}{|c|}{$\mathrm{B}_{\mathrm{i} 1}$} & \multicolumn{1}{c|}{$\mathrm{B}_{\mathrm{i} 2}$} & \multicolumn{2}{c|}{$\mathrm{B}_{\mathrm{i} 3}$} & \multicolumn{2}{c|}{$\mathrm{B}_{\mathrm{i} 4}$} & $\mathrm{~B}_{\mathrm{i} 5}$ \\
\hline $\mathrm{X}_{1}$ & $\lambda_{11}$ & $\lambda_{12}$ & $\lambda_{13}$ & $\lambda_{14}$ & $\lambda_{15}$ \\
\hline$\cdots$ & $\ldots$ & $\cdots$ & $\cdots$ & $\cdots$ & $\cdots$ \\
\hline $\mathrm{X}_{\mathrm{N}}$ & $\lambda_{\mathrm{N} 1}$ & $\lambda_{\mathrm{N} 2}$ & $\lambda_{\mathrm{N} 3}$ & $\lambda_{\mathrm{N} 4}$ & $\lambda_{\mathrm{N} 5}$ \\
\hline Weight $(\mathrm{g})$ & 0,1 & 0,3 & 0,5 & 0,7 & 0,9 \\
\hline
\end{tabular}

Source: Nedosekin, A.O. Fuzzy-multiple approach to actuarial modeling [Electronic resource] / AO Nedosekin. Access mode: http: // pensionreform.ru, free. 
Step 8 (Risk assessment of the transportation process). Now let's perform formal arithmetic actions to assess the level of investment attractiveness $\mathrm{g}$ :

$$
g=\sum_{j=1}^{5} g_{j} \sum_{i=1}^{N} r_{i} \lambda_{i j}
$$

Step 9 (Linguistic recognition). Classify the obtained value of the degree of risk on the database of Table 4. Thus, our conclusion about the level of riskiness of the transportation process takes on a linguistic form and logistics concept has the following form.

Table 4. Selected metrics classification.

\begin{tabular}{|c|c|c|c|c|c|}
\hline \multirow[t]{2}{*}{ Indicator } & \multicolumn{5}{|c|}{ The criterion of division into subsets } \\
\hline & $\begin{array}{l}\text { extremely low } \\
\text { risk }\end{array}$ & low risk & average risk & high risk & extremely high risk \\
\hline \multicolumn{6}{|c|}{$\begin{array}{c}\text { The system of fuzzy-multiple classifiers of indicators characterizing } \\
\text { the level of material risks tolerability }\end{array}$} \\
\hline $\mathrm{Fr} / \mathrm{m}-1$ & $(1 ; 1 ; 3 ; 5)$ & $(3 ; 5 ; 6 ; 8)$ & $(6 ; 8 ; 10 ; 12)$ & $(10 ; 12 ; 13 ; 15)$ & $(13 ; 15 ;+\infty ;+\infty)$ \\
\hline $\mathrm{Fr} / \mathrm{m}-2$ & $(1 ; 1 ; 2 ; 3)$ & $(2 ; 3 ; 4 ; 5)$ & $(4 ; 5 ; 6 ; 7)$ & $(6 ; 7 ; 8 ; 10)$ & $(8 ; 10 ; 10 ; 10)$ \\
\hline $\mathrm{Fr} / \mathrm{m}-3$ & $\begin{array}{c}(0 ; 0 ; 300 ; \\
1400)\end{array}$ & $\begin{array}{l}(300 ; 1400 ; \\
2500 ; 3600)\end{array}$ & $\begin{array}{l}(2500 ; 3600 ; \\
4700 ; 5800)\end{array}$ & $\begin{array}{l}(4700 ; 5800 ; \\
6900 ; 8000)\end{array}$ & $(9100 ; 10200 ;+\infty ;+\infty)$ \\
\hline $\mathrm{Fr} / \mathrm{m}-4$ & $(0 ; 0 ; 2 ; 4)$ & $(2 ; 4 ; 6 ; 9)$ & $(6 ; 9 ; 11 ; 13)$ & $(11 ; 13 ; 15 ; 17)$ & $(15 ; 17 ;+\infty ;+\infty)$ \\
\hline $\mathrm{Fr} / \mathrm{m}-5$ & $(1 ; 1 ; 2 ; 3)$ & $(2 ; 3 ; 4 ; 5)$ & $(4 ; 5 ; 6 ; 7)$ & $(6 ; 7 ; 8 ; 10)$ & $(8 ; 10 ; 10 ; 10)$ \\
\hline \multicolumn{6}{|c|}{$\begin{array}{c}\text { The system of fuzzy-multiple classifiers of indicators characterizing } \\
\text { the level of operational risks tolerability }\end{array}$} \\
\hline Fr/e-1 & $(0 ; 0 ; 8 ; 16)$ & $(8 ; 16 ; 24 ; 32)$ & $(24 ; 32 ; 40 ; 48)$ & $(40 ; 48 ; 56 ; 64)$ & $(56 ; 64 ; 100 ; 100)$ \\
\hline Fr/e-2 & $(0 ; 0 ; 11 ; 23)$ & $(11 ; 23 ; 34 ; 45)$ & $(34 ; 45 ; 56 ; 68)$ & $(56 ; 68 ; 79 ; 90)$ & $(79 ; 90 ; 100 ; 100)$ \\
\hline Fr/e-3 & $(0 ; 0 ; 5 ; 10)$ & $(5 ; 10 ; 15 ; 20)$ & $(15 ; 20 ; 25 ; 30)$ & $(25 ; 30 ; 35 ; 40)$ & $(35 ; 40 ;+\infty ;+\infty)$ \\
\hline Fr/e-4 & $(0 ; 0 ; 4 ; 8)$ & $(4 ; 8 ; 11 ; 15)$ & $(11 ; 15 ; 19 ; 23)$ & $(19 ; 23 ; 26 ; 30)$ & $(26 ; 30 ;+\infty ;+\infty)$ \\
\hline Fr/e-5 & $(0 ; 0 ; 12 ; 25)$ & $(12 ; 25 ; 37 ; 49)$ & $(37 ; 49 ; 61 ; 74)$ & $(61 ; 74 ; 86 ; 98)$ & $(86 ; 98 ; 100 ; 100)$ \\
\hline \multicolumn{6}{|c|}{$\begin{array}{c}\text { The system of fuzzy-multiple classifiers of indicators characterizing } \\
\text { the level of social risks tolerability }\end{array}$} \\
\hline Fr/e-1 & $(70 ; 80 ; 100 ; 100)$ & $(50 ; 60 ; 70 ; 80)$ & $(30 ; 40 ; 50 ; 60)$ & $(10 ; 20 ; 30 ; 40)$ & $(0 ; 0 ; 10 ; 20)$ \\
\hline Fr/e-2 & $(1 ; 1 ; 2 ; 3)$ & $(2 ; 3 ; 4 ; 5)$ & $(4 ; 5 ; 6 ; 7)$ & $(6 ; 7 ; 8 ; 10)$ & $(8 ; 10 ; 10 ; 10)$ \\
\hline Ft/e-3 & $(1 ; 1 ; 2 ; 3)$ & $(2 ; 3 ; 4 ; 5)$ & $(4 ; 5 ; 6 ; 7)$ & $(6 ; 7 ; 8 ; 10)$ & $(8 ; 10 ; 10 ; 10)$ \\
\hline
\end{tabular}

Source: Written by authors based on a fuzzy multiple approach.

The results obtained are characterized by two components: a linguistic interpretation of the level of a particular risk and the degree of reliability of the obtained result (Table 4).

First of all, considering the linguistic interpretation of the result obtained by the experts it was found that the border state is the state \# 3 - conditionally acceptable level of risk "medium risk". If the transport scenario exceeds the current state and goes into state \# 4 - an unacceptable high-risk level of risk - it is automatically discarded. However, since these variables are unclear, the level of classification reliability should be taken into account. Therefore, the rules for acceptable reliability should be established.

The threshold of reliability, in the case of material risks is set at $50 \%$, since they have only 1 level of consequences of implementation. At the same time, operational and social risks have levels 2 and 3, respectively. As a result, the experts have established a $40 \%$ confidence level for them. This is primarily due to the fact that they can lead to the realization of environmental risks.

\section{Conclusions}

1. The paper proposes a system of factors expressed in indicators reflecting the influence of the internal and external environment on the level of a risk group of perishable agricultural products transportation process. On the basis of the defined system of indicators, a fuzzymultiple model of assessment of the level of tolerability of the proposed logistics risk groups was formed.

2. In accordance with the defined approach, it is proposed, first of all, to assess the level of tolerability of all possible transportation scenarios implementation accepted apart from economic indicators. A scenario that does not meet the regulatory norms of the logistical risk tolerability level should be automatically excluded from the list of potential for implementation regardless of its level of economic attractiveness.

\section{References}

1.Bandaly D., Satir A., Shanker L. (2014). Integrated Supply Chain Risk Management via Operational Methods and Financial Instruments, International Journal of Production Research 52 (7): 2007-2025.

2. Chen J, Sohal A. S., Prajogo D. I. (2016). Supply risk mitigation: a multi-theoretical perspective. Production Planning \& Control The Management of Operations Volume 27, Issue 10. 853-863.

3.Nooraie S. V., Parast M.M. (2015). A MultiObjective Approach to Supply Chain Risk Management: 
Integrating Visibility with Supply and Demand Risk", International Journal of Production Economics 161: 192-200.

4.Nyaga, G. N., Lynch, D. F., Marshall, D., \& Ambrose, E. (2013). Power Asymmetry, Adaptation and Collaboration in Dyadic Relationships Involving a Powerful Partner. Journal of Supply Chain Management, 49(3), 42-65.

5.Oracle (2013). Managing the Value Chain in Turbulent Times. Dynamic Markets Limited. Independent Market Research Report Commissioned by Oracle.

6.Tang O. Musa S. N. (2011). Identifying Risk Issues and Research Advancements in Supply Chain Risk Management. International Journal of Production Economics 133 (1): 25-34.

7.Vilko J., Ritala P., Edelmann J. (2014). On Uncertainty in Supply Chain Risk Management. The International Journal of Logistics Management 25 (1): 319.

8. Wildgoose, N., P. Brennan, and S. Thompson. (2012). Understanding Your Supply Chain to Reduce the Risk of Supply Chain Disruption. Journal of Business Continuity \& Emergency Planning 6 (1): 55-67.

\section{Список літератури}

1.Bandaly D., Satir A., Shanker L. Integrated Supply Chain Risk Management via Operational Methods and Financial Instruments, International Journal of Production Research. 2014. 52 (7): 20072025.

2. Chen J, Sohal A. S., Prajogo D. I. Supply risk mitigation: a multi-theoretical perspective. Production Planning \& Control The Management of Operations. 2016. Volume 27, Issue 10. 853-863.

3.Nooraie S. V., Parast M.M. A Multi-Objective Approach to Supply Chain Risk Management: Integrating Visibility with Supply and Demand Risk", International Journal of Production Economics. 2015. 161: 192-200.

4.Nyaga, G. N., Lynch, D. F., Marshall, D., \& Ambrose, E. Power Asymmetry, Adaptation and Collaboration in Dyadic Relationships Involving a Powerful Partner. Journal of Supply Chain Management, 2013, 49(3), 42-65.

5.Oracle. Managing the Value Chain in Turbulent Times. Dynamic Markets Limited. Independent Market Research Report Commissioned by Oracle. 2013.

6.Tang $O$. Musa S. N. Identifying Risk Issues and Research Advancements in Supply Chain Risk Management. International Journal of Production Economics. 2011. 133 (1): 25-34.

7. Vilko J., Ritala P., Edelmann J. On Uncertainty in Supply Chain Risk Management. The International Journal of Logistics Management. 2014. 25 (1): 3-19.

8. Wildgoose, N., P. Brennan, and S. Thompson. Understanding Your Supply Chain to Reduce the Risk of Supply Chain Disruption. Journal of Business Continuity \& Emergency Planning. 2012. 6 (1): 55-67.
МОДЕЛЬ ОЦНКИ РІВНЯ ДОПУСТИМОСТІ

РИЗИКІВ ПРОЦЕСУ ТРАНСПОРТУВАННЯ ШВИДКОПСУВНОЇ АГАРНОЇ ПРОДУКЦІЇ

О. М. Загурський

Анотація. Рівень допустимості ризику для ланцюгів постачань аграрної продукції внаслідок іiі особливостей, перш за все пов'язаних із обмеженими термінами зберігання, є комплексним показником, який відображає ймовірність настання і важкість несприятливої події (ризикової події). При цьому, вплив на факт настання ризикової події справляє значна кількість факторів зовнішнього i внутрішнього середовища, виражених в сукупності певних показників.

Значимість даних показників, рівно, як і вектор сили їх впливу, унікальні для кожного окремого фактора. Проте найбільший вплив i певну унікальність мають показники впливу транспортних факторі на ризиковість в логістики ланцюгів постачань.

В статті запропонована системи факторів, виражених в індикативних показниках, що відображають вплив внутрішнього і зовнішнього середовища на рівень ризиковості процесу транспортування швидкопсувних аграрних продуктів.

Одним 3 найбільш придатних для побудови моделі оцінки рівня допустимості логістичних ризиків процесу транспортування швидкопсувної агарної продукції є нечітко-множинний підхід.

На основі визначеної системи індикативних показників була сформована нечітко-множинна модель оцінки рівня допустимості запропонованих груп логістичних ризиків. Відповідно до визначеного підходу пропонується в першу чергу, незалежно від економічних показників, оцінювати рівень допустимості всіх прийнятих до можливої реалізації сценаріїв транспортування. Сценарій, який не відповідає умовно нормативним значенням допустимості рівня логістичного ризику, повинен бути автоматично виключені зі списку можливих до реалізації незалежно від рівня його економічної привабливості.

Ключові слова: аграрна продукція, ланцюги постачань, ризик, система показників, транспортування.

\section{МОДЕЛЬ ОЦЕНКИ УРОВНЯ ДОПУСТИМОСТИ \\ РИСКОВ ПРОЦЕССА ТРАНСПОРТИРОВКИ СКОРОПОРТЯЩЕЙСЯ АГРАРНОЙ ПРОДУКЦИИ О. Н. Загурский}

Аннотация. Уровень допустимости риска для цепей поставок аграрной продукции вследствие ее особенностей, прежде всего связанных с ограниченными сроками хранения, является комплексным показателем, который отражает вероятность наступления и тяжесть неблагоприятного (рискового) события. При этом, влияние на факт наступления рискового события производит значительное количество факторов внешней и внутренней среды, выраженных в совокупности определенных показателей. 
Значимость данных показателей, ровно, как и вектор силы их влияния, уникальные для каждого отдельного фактора. Однако наибольшее влияние и определенную уникальность имеют показатели воздействия транспортных факторе на рискованность в логистике цепей поставок.

В статье предложена система факторов, выраженных в индикативных показателях, отражающих влияние внутренней и внешней среды на уровень рискованности процесса транспортировки скоропортящихся аграрных продуктов. Одним из наиболее подходящих для построения модели оценки уровня допустимости логистических рисков процесса транспортировки скоропортящейся аграрной продукции является нечетко-множественный подход.

На его основе предложеной системы индикативных показателей была сформирована нечетко-множественная модель оценки уровня допустимости предложенных групп логистических рисков. Согласно ей предлагается в первую очередь, независимо от экономических показателей, оценивать уровень допустимости всех принятых к возможной реализации сценариев транспортировки. Сценарий, который не соответствует условно нормативным значениям допустимости уровня логистического риска, должен быть автоматически исключены из списка возможных к реализации независимо от уровня его экономической привлекательности.

Ключевые слова: аграрная продукция, цепи поставок, риск, система показателей, транспортировки.

О. М. Загурський ORCID 0000-0002-5407-8466. 